Iermakov, S., Ivashchenko, O., Khudolii, O., \& Chernenko, S. (2020). Strength Abilities: Assessment of Training Effects of Strength Loads in Boys Aged 8 Years. Teoriâ ta Metodika Fizičnogo Vihovannâ, 20(3), 174-181.

https://doi.org/10.17309/tmfv.2020.3.07

ISSN 1993-7989 (print). ISSN 1993-7997 (online)

\title{
STRENGTH ABILITIES: ASSESSMENT OF TRAINING EFFECTS OF STRENGTH LOADS IN BOYS AGED 8 YEARS
}

\author{
Sergii Iermakov ${ }^{1 A B C D}$, Olha Ivashchenko ${ }^{2 A B C D}$, Oleg Khudolii ${ }^{2 A B C D}$, Sergii Chernenko ${ }^{3 A B C D}$ \\ ${ }^{1}$ Gdansk University of Physical Education and Sport \\ ${ }^{2}$ H.S. Skovoroda Kharkiv National Pedagogical University \\ ${ }^{3}$ Donbas State Engineering Academy
}

Authors' Contribution: A - Study design; B - Data collection; C - Statistical analysis; D - Manuscript Preparation; E - Funds Collection

Corresponding Author: Sergii Iermakov, E-mail: sportart@gmail.com

Accepted for Publication: September 20, 2020

Published: September 25, 2020

DOI: 10.17309/tmfv.2020.3.07

\begin{abstract}
The purpose of this paper is to determine the impact of strength training modes on the dynamics of training effects in 8 -year-old boys.

Materials and methods. The study participants were 48 boys aged 8 . The experiment was performed using a $2^{2}$ factorial design. The study implemented the first variant of the combined method for developing arm and shoulder muscles (station I), strength of abdominal muscles (station II), strength of back muscles (station III), and strength of leg muscles (station IV). The study materials were processed using the IBM SPSS 22 statistical analysis program. Discriminant analysis was performed. The study examined the impact of four variants of strength load on the immediate training effect $\left(\mathrm{ITE}_{1}\right)$ after performing exercises at four stations, the immediate training effect $\left(\mathrm{ITE}_{2}\right)$ after training, and the delayed training effect (DTE) 24 hours after training.

Results. The findings indicate that each of the variants of strength load can be effectively used depending on educational objectives of both one or a series of physical education lessons, and also show that the ITE and DTE of strength training depend on the initial level of fitness and the total amount of strength training in a physical education lesson.

Conclusions. The findings point to the possibility of using a discriminant function to assess and predict the development of strength in 8-year-old boys. The study confirmed the effectiveness of using factorial designs to obtain objective data on the dynamics of training effects in primary school pupils.

Keywords: boys aged 8 years, training effects, strength training, combined method of strength development, discriminant analysis, factorial design.
\end{abstract}

\section{Introduction}

The basis for managing training effects of physical exercises in schoolchildren's physical education is control and targeted regulation of rest intervals between exercise repetitions (Ivashchenko, 2016; Bosenko, 2016; Veremeenko, 2019).

One of the methods based on the regulation of rest intervals between exercises and alternation of muscle training modes is the combined method of strength development. Since the methods of maximal and isometric effort are not recommended to be used separately when training children, they can be successfully used in combination with others in the combined method of strength development (Kuramshin,

(C) Sergii Iermakov, Olha Ivashchenko, Oleg Khudolii, Sergii Chernenko, 2020.
Grigorev, \& Latysheva, 2004; Khudolii \& Ivashchenko, 2014; Ivashchenko, 2016; Veremeenko, 2019).

The need for balanced efforts in both physical education and sports training is indicated in papers by Washabaugh, Augenstein, and Krishnan (2020), Benzing, and Schmidt (2019), Haghighi, Mohammadtaghipoor, Hamedinia, and Harati (2019). Thus, Bogdanis, Donti, Papia, Donti, Apostolidis, and Sands (2019), Wertheimer, Antekolovic, and Matkovic (2018) note a positive effect of plyometric loads on the level of motor fitness of both children and adults. Lovric, Mandic Jelaska, and Bilic (2018), Marttinen, Fredrick III, and Silverman (2018) highlight the need to accurately determine the effects of physical loads in children.

Thus, the issue of controlling strength loads in physical education lessons of primary school pupils is relevant and requires additional research. 
The purpose of the study is to determine the impact of strength training modes on the dynamics of training effects in boys aged 8 years.

\section{Materials and methods}

\section{Study participants}

The study participants were boys aged 8 years $(n=48)$. The children and their parents were fully informed about all the features of the study and gave their consent to participate in the experiment.

\section{Study organization}

To solve the tasks set, theoretical and empirical methods were used: analysis and generalization of scientific and methodological literature; modeling, pedagogical observation and experiment, discriminant analysis.

To determine the dynamics of strength training effects in boys aged 8 years, the study carried out an experiment according to the plan given in Table 1 . Variant I of the combined method was used to strengthen arm and shoulder muscles (station I), abdominal muscles (station II), back muscles (station III), and leg muscles (station IV). At each station, the following methods were used: dynamic effort method, maximal effort method, isometric effort method, repeated effort method. The modes of performance for each group, for the indicated stations are given in Table 1. The study examined

Table 1. Factorial design in studying the influence of different modes of the combined method of strength development (variant I) in primary school children $\left(\mathrm{X}_{1}-\right.$ number of repetitions in a set; $\mathrm{X}_{2}$ - rest interval, $\mathrm{s}$ )

\begin{tabular}{llll}
\hline $\begin{array}{c}\text { No. } \\
\text { of strength } \\
\text { load variant }\end{array}$ & \multicolumn{1}{c}{ Method } & $\mathbf{X}_{1}$ & $\mathbf{X}_{2}$ \\
\hline \multirow{4}{*}{ I } & Dynamic effort method & $3-$ & $30-$ \\
& Maximal effort method & $1-$ & $30-$ \\
& Isometric effort method & $3-$ & $30-$ \\
& Repeated effort method & $6-$ & $30-$ \\
\hline \multirow{4}{*}{ II } & Dynamic effort method & $5+$ & $30-$ \\
& Maximal effort method & $3+$ & $30-$ \\
& Isometric effort method & $5+$ & $30-$ \\
& Repeated effort method & $12+$ & $30-$ \\
\hline \multirow{3}{*}{ III } & Dynamic effort method & $3-$ & $60+$ \\
& Maximal effort method & $1-$ & $60+$ \\
& Isometric effort method & $3-$ & $60+$ \\
& Repeated effort method & $6-$ & $60+$ \\
\hline & Dynamic effort method & $5+$ & $60+$ \\
& Maximal effort method & $3+$ & $60+$ \\
& Isometric effort method & $5+$ & $60+$ \\
& Repeated effort method & $12+$ & $60+$ \\
\hline & & &
\end{tabular}

the impact of four variants of strength load on the immediate training effect $\left(\right.$ ITE $\left._{1}\right)$ after performing exercises at four stations, the immediate training effect $\left(\mathrm{ITE}_{2}\right)$ after training, and the delayed training effect (DTE) 24 hours after training. At each station, the following exercises were performed: Station I. Exercises for arm and shoulder muscles.

1. Dynamic effort method. Knee push-ups. The exercise is performed as quickly as possible.

2. Maximal effort method. Weighted push-ups (stuffed ball).

3. Isometric effort method. Knee push-ups. The exercise is performed with two stops and fixation of joint angles (5s).

4. Repeated effort method. Knee push-ups. Station II. Exercises to strengthen abdominal muscles.

1. Dynamic effort method. Sit-ups. The exercise is performed as quickly as possible.

2. Maximal effort method. Hanging 90-degree leg raises on wall bars.

3. Isometric effort method. Decline bench 90-degree leg raises. The exercise is performed with two stops and fixation of joint angles ( $5 \mathrm{~s}$ ).

4. Repeated effort method. Decline bench leg raises to plow. Station III. Exercises to strengthen back muscles.

1. Dynamic effort method. Trunk lift. The exercise is performed as quickly as possible.

2. Maximal effort method. Trunk lift on a pommel horse with feet supported under wall bars.

3. Isometric effort method. Trunk lift with two stops and holding each static position for $5 \mathrm{~s}$. The exercise is performed with two stops and fixation of joint angles (5s) (hold positions in the upper point and horizontally).

4. Repeated effort method. The same starting position. Trunk lift.

Station IV. Exercises to strengthen leg muscles.

1. Dynamic effort method. Squats. The exercise is performed as quickly as possible.

2. Maximal effort method. Weighted squats (stuffed ball, dumbbells).

3. Isometric effort method. Weighted squats with stops. The exercise is performed with two stops and fixation of joint angles (5 s) $\left(90^{\circ}, 135^{\circ}\right)$.

4. Repeated effort method. Squats.

During the experiment, the study recorded the results of the following tests: 1 . Push-ups. 2. Speed push-ups, 3 times. 3. Sit-ups in 30 seconds. 4 . Trunk lift in 10 seconds. 5. Standing long jump.

On the first day before the experiment, the study recorded the results of Test 2 "Speed push-ups, 3 times", Test 1 "Push-ups", Test 3 "Sit-ups in 30 seconds", Test 4 "Trunk lift in 10 seconds", Test 5 "Standing long jump". After performing the exercises at station I - Tests 2, 1; at station II - Test 3; at station III - Test 4; at station IV - Test 5. After the lesson Tests 2, 1, 3, 4. Twenty-four hours after training - Tests 2, $1,3,4,5$. The dynamics of test results was determined as a percentage relative to the initial level.

\section{Statistical analysis}

The study materials were processed using the IBM SPSS 22 statistical analysis program. In the process of discriminant analysis, the researchers created a prognostic model for group membership. 
For each canonical discriminant function, the study calculated: eigenvalue, dispersion percentage, canonical correlation, Wilks' Lambda, Chi-square.

The study protocol was approved by the Ethical Committee of H. S. Skovoroda Kharkiv National Pedagogical University.

\section{Results}

The results of the $2^{2}$ full factorial experiment are given in Tables 2-4.

The results of the analysis of the immediate training effect $\left(\mathrm{ITE}_{1}\right)$ after performing exercises at four stations: station I "Exercises for arm and shoulder muscles"; station II "Exercises to strengthen abdominal muscles"; station III "Exercises to strengthen back muscles"; station IV "Exercises to strengthen leg muscles" are given below (see Table 2).

The first load variant has the largest ITE $_{1}$ on arm and shoulder muscles relative to the others $(p=0.005)$. The fourth variant has a larger ITE 1 on speed strength of arm and shoulder muscles than the first one $(p=0.001)$. The first load variant has the largest ITE $_{1}$ on abdominal muscles relative to the others $(p=0.001)$. The fourth load variant has the smallest ITE $_{1}$ relative to the others $(p=0.001)$. The first load variant has the largest ITE $_{1}$ on back muscles relative to the others $(p=0.001)$. The fourth load variant has the smallest ITE relative to the others $(p=0.001)$. The difference between the ITE $_{1}$ of the first, second, and third load variants is not statisti-

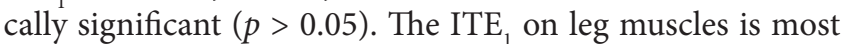
influenced by the third $(p=0.019, p=0.043)$ and fourth load variants $(p=0.012)$.

Thus, the ITE $\mathrm{I}_{1}$ of physical exercises for different muscle groups depends on the variant of strength load. The choice of the variant of strength load is influenced by the focus and amount of $\mathrm{ITE}_{1}$ :
- the first load variant has the largest ITE $\mathrm{I}_{1}$ on arm and shoulder muscles, the test result decreases to $84.98 \%$ relative to the initial level, this variant has a $7.932 \%$ larger effect (variant II), 4.278\% (variant III), 8.331\% (IV) relative to the others;

- the fourth variant leads to an increase in the speed of strength training, the test result is $97.45 \%$ relative to the initial level and has an $11.936 \%$ larger effect than the first variant;

- the first load variant has the largest ITE on abdominal $_{1}$ muscles, the test result decreases to $89.63 \%$ relative to the initial level, this variant has an $11.936 \%$ larger effect than the fourth variant;

- the first load variant has the largest ITE on back $_{1}$ muscles, the test result decreases to $92.03 \%$ relative to the initial level, this variant has a $5.746 \%$ larger effect than the fourth variant;

- the third and fourth load variants have the largest $\mathrm{ITE}_{1}$ on leg muscles.

The data of the analysis of the immediate training effect (ITE $)$ after training are shown in Table 3.

The first load variant has the largest ITE $_{2}$ on arm and shoulder muscles relative to the others ( $p=0.007-0.05)$. The difference between the $\mathrm{ITE}_{2}$ on speed strength of arm and shoulder muscles of the variants of strength load is not statistically significant $(p>0.05)$. The first and second load variants have the largest ITE 2 on abdominal muscles relative to the others $(p=0.001)$. The third load variant has the smallest ITE relative to the others $(p=0.001)$. The fourth load variant has the smallest ITE on back muscles relative to the others $(p=0.035)$. The difference between the ITE ${ }_{2}$ of the first, second, and third load variants is not statistically significant $(p>0.05)$. The difference between the impacts of the variants of strength load on the ITE 2 on leg muscles is not statistically significant.

Table 2. The results of the impact of different variants of strength load on the dynamics of immediate training effect (ITE ${ }_{1}$ ) after performing exercises in boys aged 8 years $(n=12)$

\begin{tabular}{|c|c|c|c|c|c|c|c|c|c|c|}
\hline No. & Test & Variant & $\mathbf{X}$ & s & $\Delta_{1-2-4}$ & $\Delta_{2-3-4}$ & $\Delta_{3-4}$ & $p_{1-2-4}$ & $\mathbf{p}_{2-3-4}$ & $\mathbf{p}_{3-4}$ \\
\hline \multirow[t]{4}{*}{1} & Push-ups & 1 & 84.98 & 4.737 & & & & & & \\
\hline & & 2 & 92.91 & 7.784 & -7.932 & & & 0.005 & & \\
\hline & & 3 & 89.25 & 6.419 & -4.278 & 3.654 & & 0.077 & 0.209 & \\
\hline & & 4 & 93.31 & 2.104 & -8.331 & -0.399 & -4.053 & 0.001 & 0.865 & 0.050 \\
\hline \multirow[t]{4}{*}{2} & Speed push-ups, 3 times & 1 & 109.39 & 6.009 & & & & & & \\
\hline & & 2 & 106.56 & 4.579 & 2.834 & & & 0.185 & & \\
\hline & & 3 & 105.24 & 5.706 & 4.148 & 1.314 & & 0.097 & 0.521 & \\
\hline & & 4 & 97.45 & 5.489 & 11.936 & 9.102 & 7.788 & 0.001 & 0.001 & 0.003 \\
\hline \multirow[t]{4}{*}{3} & Sit-ups in 30 seconds & 1 & 89.63 & 6.103 & & & & & & \\
\hline & & 2 & 90.46 & 4.515 & -0.831 & & & 0.694 & & \\
\hline & & 3 & 92.77 & 0.857 & -3.136 & -2.305 & & 0.092 & 0.095 & \\
\hline & & 4 & 98.15 & 2.735 & -8.517 & -7.685 & -5.380 & 0.001 & 0.001 & 0.001 \\
\hline \multirow[t]{4}{*}{4} & Trunk lift in 10 seconds & 1 & 92.03 & 6.271 & & & & & & \\
\hline & & 2 & 91.94 & 6.170 & 0.093 & & & 0.970 & & \\
\hline & & 3 & 94.02 & 7.074 & -1.990 & -2.082 & & 0.474 & 0.430 & \\
\hline & & 4 & 97.78 & 3.282 & -5.746 & -5.839 & -3.757 & 0.010 & 0.007 & 0.109 \\
\hline \multirow[t]{4}{*}{5} & Standing long jump & 1 & 100.32 & 2.408 & & & & & & \\
\hline & & 2 & 99.69 & 2.473 & 0.630 & & & 0.519 & & \\
\hline & & 3 & 97.06 & 3.768 & 3.262 & 2.632 & & 0.019 & 0.043 & \\
\hline & & 4 & 98.00 & 1.644 & 2.320 & 1.690 & -0.942 & 0.012 & 0.055 & 0.436 \\
\hline
\end{tabular}


Table 3. The results of the impact of different variants of strength load on the dynamics of immediate training effect (ITE2) after training in boys aged 8 years $(n=12)$

\begin{tabular}{|c|c|c|c|c|c|c|c|c|c|c|}
\hline No. & Test & Variant & $\mathbf{X}$ & s & $\Delta_{1-2-4}$ & $\Delta_{2-3-4}$ & $\Delta_{3-4}$ & $\mathbf{p}_{1-2-4}$ & $\mathbf{p}_{2-3-4}$ & $\mathbf{p}_{3-4}$ \\
\hline \multirow[t]{4}{*}{1} & Push-ups & 1 & 84.85 & 2.190 & & & & & & \\
\hline & & 2 & 90.53 & 6.283 & -5.680 & & & 0.007 & & \\
\hline & & 3 & 89.25 & 6.419 & -4.407 & 1.273 & & 0.035 & 0.615 & \\
\hline & & 4 & 86.53 & 1.765 & -1.688 & 3.992 & 2.719 & 0.050 & 0.044 & 0.171 \\
\hline \multirow[t]{4}{*}{2} & Speed push-ups, 3 times & 1 & 108.31 & 7.183 & & & & & & \\
\hline & & 2 & 106.42 & 7.196 & 1.889 & & & 0.511 & & \\
\hline & & 3 & 105.66 & 7.077 & 2.647 & 0.758 & & 0.373 & 0.790 & \\
\hline & & 4 & 104.04 & 7.372 & 4.267 & 2.378 & 1.620 & 0.165 & 0.414 & 0.588 \\
\hline \multirow[t]{4}{*}{3} & Sit-ups in 30 seconds & 1 & 89.78 & 3.587 & & & & & & \\
\hline & & 2 & 89.10 & 5.277 & 0.676 & & & 0.711 & & \\
\hline & & 3 & 95.55 & 3.301 & -5.767 & -6.443 & & 0.001 & 0.001 & \\
\hline & & 4 & 92.36 & 2.581 & -2.583 & -3.259 & 3.185 & 0.055 & 0.064 & 0.015 \\
\hline \multirow[t]{4}{*}{4} & Trunk lift in 10 seconds & 1 & 91.28 & 6.575 & & & & & & \\
\hline & & 2 & 91.54 & 4.237 & -0.263 & & & 0.903 & & \\
\hline & & 3 & 93.68 & 4.785 & -2.406 & -2.142 & & 0.317 & 0.238 & \\
\hline & & 4 & 95.00 & 3.761 & -3.722 & -3.458 & -1.316 & 0.103 & 0.039 & 0.462 \\
\hline \multirow[t]{4}{*}{5} & Standing long jump & 1 & 98.99 & 2.282 & & & & & & \\
\hline & & 2 & 98.60 & 2.940 & 0.399 & & & 0.706 & & \\
\hline & & 3 & 99.17 & 3.621 & -0.171 & -0.570 & & 0.891 & 0.662 & \\
\hline & & 4 & 99.18 & 2.309 & -0.184 & -0.583 & -0.013 & 0.847 & 0.584 & 0.992 \\
\hline
\end{tabular}

Table 4. The results of the impact of different variants of strength load on the dynamics of delayed training effect (DTE) 24 hours after training in boys aged 8 years $(n=12)$

\begin{tabular}{|c|c|c|c|c|c|c|c|c|c|c|}
\hline No. & Test & Variant & $\mathrm{X}$ & $\mathrm{s}$ & $\Delta_{1-2-4}$ & $\Delta_{2-3-4}$ & $\Delta_{3-4}$ & $p_{1-2-4}$ & $\mathbf{p}_{2-3-4}$ & $p_{3-4}$ \\
\hline \multirow[t]{4}{*}{1} & Push-ups & 1 & 96.57 & 3.615 & & & & & & \\
\hline & & 2 & 94.37 & 7.551 & 2.200 & & & 0.366 & & \\
\hline & & 3 & 101.39 & 3.244 & -4.824 & -7.024 & & 0.002 & 0.006 & \\
\hline & & 4 & 94.81 & 4.273 & 1.750 & -0.450 & 6.574 & 0.290 & 0.857 & 0.001 \\
\hline \multirow[t]{4}{*}{2} & Speed push-ups, 3 times & 1 & 102.60 & 2.164 & & & & & & \\
\hline & & 2 & 106.33 & 5.143 & -3.723 & & & 0.028 & & \\
\hline & & 3 & 104.20 & 6.091 & -1.599 & 2.124 & & 0.401 & 0.344 & \\
\hline & & 4 & 102.83 & 4.295 & -0.228 & 3.495 & 1.371 & 0.871 & 0.075 & 0.531 \\
\hline \multirow[t]{4}{*}{3} & Sit-ups in 30 seconds & 1 & 95.46 & 2.141 & & & & & & \\
\hline & & 2 & 95.83 & 2.813 & -0.370 & & & 0.713 & & \\
\hline & & 3 & 95.55 & 3.301 & -0.088 & 0.282 & & 0.939 & 0.816 & \\
\hline & & 4 & 94.81 & 4.273 & 0.642 & 1.013 & 0.731 & 0.646 & 0.476 & 0.644 \\
\hline \multirow[t]{4}{*}{4} & Trunk lift in 10 seconds & 1 & 97.68 & 3.460 & & & & & & \\
\hline & & 2 & 97.79 & 3.643 & -0.113 & & & 0.936 & & \\
\hline & & 3 & 94.64 & 8.972 & 3.038 & 3.150 & & 0.286 & 0.240 & \\
\hline & & 4 & 94.81 & 4.273 & 2.861 & 2.974 & -0.176 & 0.085 & 0.067 & 0.952 \\
\hline \multirow[t]{4}{*}{5} & Standing long jump & 1 & 99.96 & 2.139 & & & & & & \\
\hline & & 2 & 99.89 & 2.590 & 0.075 & & & 0.937 & & \\
\hline & & 3 & 101.80 & 4.576 & -1.841 & -1.916 & & 0.220 & 0.193 & \\
\hline & & 4 & 94.81 & 4.273 & 5.146 & 5.071 & 6.986 & 0.001 & 0.001 & 0.001 \\
\hline
\end{tabular}

Thus, the ITE of physical exercises for different muscle groups depends on the variant of strength load. The choice of the variant of strength load is influenced by the focus and amount of $\mathrm{ITE}_{2}$.

The results of the analysis of the delayed training effect (DTE) 24 hours after training are shown in Table 4.

The third load variant has the largest DTE on arm and shoulder muscles relative to the others $(p=0.002-0.006)$. The difference in the DTE on speed strength of arm and shoulder muscles between the variants of strength load is not statistically significant $(p>0.05)$. The difference between the impacts of the variants of strength load on the DTE on abdominal and back muscles is not statistically significant $(p>0.05)$. The fourth load variant has the largest DTE on leg muscles relative to the others $(p=0.001)$.

Thus, the DTE depends on the variant of strength load. The choice of the variant of strength load depends on the muscle group. 
Table 5. Structure matrix. Boys aged 8 years

\begin{tabular}{|c|c|c|c|c|c|c|c|c|c|c|}
\hline \multirow[t]{2}{*}{ Station } & \multirow[t]{2}{*}{ Indicators } & \multicolumn{3}{|c|}{$\begin{array}{c}\text { ITE }_{1} \\
\text { Function }\end{array}$} & \multicolumn{3}{|c|}{$\begin{array}{c}\text { ITE }_{2} \\
\text { Function }\end{array}$} & \multicolumn{3}{|c|}{$\begin{array}{c}\text { DTE } \\
\text { Function }\end{array}$} \\
\hline & & 1 & 2 & 3 & 1 & 2 & 3 & 1 & 2 & 3 \\
\hline \multirow{2}{*}{$\begin{array}{l}\text { Station I "Exercises } \\
\text { for arm and shoulder } \\
\text { muscles" }\end{array}$} & Push-ups & -0.275 & 0.604 & -0.739 & -0.175 & 0.854 & -0.423 & 0.443 & -0.542 & 0.263 \\
\hline & $\begin{array}{l}\text { Speed push-ups, } \\
3 \text { times }\end{array}$ & 0.650 & -0.265 & -0.200 & -0.113 & -0.102 & 0.671 & 0.036 & 0.438 & 0.896 \\
\hline $\begin{array}{l}\text { Station II "Exercises } \\
\text { to strengthen abdom- } \\
\text { inal muscles" }\end{array}$ & $\begin{array}{l}\text { Sit-ups in } \\
30 \text { seconds }\end{array}$ & -0.667 & 0.082 & 0.330 & 0.639 & 0.578 & 0.093 & 0.068 & 0.173 & 0.097 \\
\hline $\begin{array}{l}\text { Station III "Exercises } \\
\text { to strengthen back } \\
\text { muscles" }\end{array}$ & $\begin{array}{l}\text { Trunk lift in } \\
10 \text { seconds }\end{array}$ & -0.328 & -0.010 & 0.244 & 0.271 & 0.040 & -0.723 & -0.002 & 0.491 & -0.406 \\
\hline $\begin{array}{l}\text { Station IV "Exer- } \\
\text { cises to strengthen leg } \\
\text { muscles" }\end{array}$ & $\begin{array}{l}\text { Standing long } \\
\text { jump }\end{array}$ & 0.303 & 0.284 & 0.818 & 0.091 & -0.039 & 0.012 & 0.656 & 0.480 & 0.218 \\
\hline
\end{tabular}

Table 6. Functions at group centroids. Boys aged 8 years

\begin{tabular}{lccc}
\hline \multirow{2}{*}{ Indicators } & \multicolumn{3}{c}{ Training effect } \\
\cline { 2 - 4 } & ITE $_{1}$ & ITE $_{2}$ & DTE \\
\hline variant I & 1.250 & -0.206 & 0.391 \\
variant II & 0.815 & -1.283 & -0.267 \\
variant III & -0.330 & 1.003 & 1.416 \\
variant IV & -1.871 & 0.700 & -1.495 \\
\hline
\end{tabular}

Thus, the DTE of physical exercises for different muscle groups depends on the variant of strength load. The choice of the variant of strength load is influenced by the focus and amount of DTE.

To assess the overall impact of different variants of strength load on the formation of training effects, a discriminant analysis was performed. Tables 5-6 show the results of the discriminant analysis.

The analysis of the immediate training effect $\left(\mathrm{ITE}_{1}\right)$ after performing exercises at the stations showed that the first canonical function explains $71.4 \%$ of the variation of results, the second one $-24.0 \%$, which indicates a high informativeness of the first and second canonical functions $\left(r_{1}=0.780 ; r_{2}=0.585\right)$.

The verification of the first and second functions showed their high discriminative ability and value in interpretation with respect to the general population $\left(\lambda_{1}=0.234 ; p_{1}=0.001\right.$; $\left.\lambda_{2}=0.597 ; p_{2}=0.001\right)$. The first function characterizes the impact of four variants of strength load on the ITE Ifter $_{1}$ performing exercises at the station.

Structure coefficients show that the most significant changes in the ITE 1 are associated with the second station's "exercises to strengthen abdominal muscles" and the first station's "exercises to strengthen arm and shoulder muscles" $\left(r_{2}=-0.667, r_{1}=0.650\right.$, see Table 5 , variant 1$)$. During a discriminant analysis, it was found that $76 \%$ of cases were classified correctly. The analysis of group centroids for the ITE shows that at the positive pole of the first function, there are the centroids of training effects of the first and second load variants, at the negative pole - the centroids of the third and fourth variants of strength load. Thus, the differentiation of training effects is observed in the response to strength load (see Table 6, ITE $_{1}$. The fourth variant of strength load has the largest overall impact on the ITE .
The analysis of the immediate training effect $\left(\mathrm{ITE}_{2}\right)$ after training showed that the first canonical function explains $72.3 \%$ of the variation of results, the second one $-21.9 \%$, which indicates a high informativeness of the first and second canonical functions $\left(r_{1}=0.689 ; r_{2}=0.463\right)$.

The verification of the first and second functions showed their high discriminative ability and value in interpretation with respect to the general population $\left(\lambda_{1}=0.385 ; p_{1}=0.001\right.$; $\left.\lambda_{2}=0.732 ; p_{2}=0.085\right)$. The first function characterizes the impact of four variants of strength load on the $\mathrm{ITE}_{2}$ after training.

Structure coefficients show that the most significant changes in the ITE $_{2}$ are associated with the second station's "exercises to strengthen abdominal muscles" $\left(r_{2}=0.639\right.$, see Table 5, $\mathrm{ITE}_{2}$ ). During a discriminant analysis, it was found that $56 \%$ of cases were classified correctly. The analysis of group centroids for the $\mathrm{ITE}_{2}$ shows that at the positive pole of the first function, there are the centroids of training effects of the third and fourth load variants, at the negative pole - the centroids of the second and first variants of strength load. Thus, in the response to strength load, the differentiation of training effects is observed between the variants of strength load (see Table 6, ITE $_{2}$. The second variant of strength load has the largest overall impact on the $\mathrm{ITE}_{2}$.

The analysis of the delayed training effect (DTE) 24 hours after training showed that the first canonical function explains $76.4 \%$ of the variation of results, the second one $18.9 \%$, which indicates a high informativeness of the first and second canonical functions $\left(r_{1}=0.734 ; r_{2}=0.473\right)$.

The verification of the first and second functions showed their high discriminative ability and value in interpretation with respect to the general population $\left(\lambda_{1}=0.334 ; p_{1}=0.001\right.$; $\left.\lambda_{2}=0.724 ; p_{2}=0.072\right)$. The first function characterizes the impact of four variants of strength load on the DTE 24 hours after training.

Structure coefficients show that the most significant changes in the DTE are associated with the fourth station's "exercises to strengthen leg muscles" ( $r_{2}=0.656$, see Table 5 , DTE). During a discriminant analysis, it was found that $60 \%$ of cases were classified correctly. The analysis of group centroids for the DTE shows that at the positive pole of the first function, there are the centroids of training effects of the first and third load variants, at the negative pole - the centroids 
of the second and fourth variants of strength load. Thus, in the response to strength load, the differentiation of training effects is observed between the variants of strength load (see Table 6, DTE). The fourth variant of strength load has the largest overall impact on the DTE.

Consequently, the ITE ITE $_{2}$, and DTE of physical exercises for different muscle groups depend on the variant of strength load. The choice of the variant of strength load is influenced by the focus and amount of training effect of strength exercises.

\section{Discussion}

The paper assumed that the formation of $\mathrm{ITE}_{1}, \mathrm{ITE}_{2}$, and DTE of exercises for different muscle groups in 8-year-old boys is influenced by the variants of strength load, as well as the methods of strength development in physical education lessons. According to scientific data, the study assumed that a combined method of the first variant, which includes a comprehensive development of strength of different muscle groups at four stations using the methods of dynamic effort maximal effort - isometric effort - repeated effort may be an effective method of strength development in primary school children (Ivashchenko, 2016, 2017; Cieślicka \& Ivashchenko, 2017; Khudolii, Ivashchenko, Iermakov, Nosko, \& Marchenko, 2019).

The findings show that each of the variants of strength load can be effectively used depending on the educational objectives of both one and a series of physical education lessons, and also indicate that the ITE and DTE of strength training depend on the initial level of fitness and the total amount of strength training in a physical education lesson. This supports the conclusion of researchers about the need for structural and functional analysis of the effects of physical exercises and rest intervals in strength development of primary school pupils (Ivashchenko, Nosko, \& Ferents, 2019; Khudolii, Ivashchenko, Iermakov, Veremeenko, \& Lopatiev, 2019). The results of discriminant analysis corroborate the findings of Bosenko (2016) about age and gender peculiarities of the response to physical load in schoolchildren aged 7-16.

The study proved the effectiveness of using the combined method of strength development in the suggested strength training modes in the educational process of boys aged 8 years. The paper supplements the data on the need to manage training loads in the process of learning and strength development in school-age children (Khudolii et al., 2019; Khudolii, Ivashchenko, Iermakov, Veremeenko, \& Lopatiev, 2019; Khudolii, Iermakov, \& Bartik, 2020).

The findings point to the possibility of using the discriminant function to assess and predict the development of strength in 8-year-old boys. In physical education and sport, the discriminant function is used to determine the dynamics of physical fitness of children aged 9-12 under the influence of fitness programs, for the final control of functional and motor fitness of children and adolescents (Ivashchenko, Khudolii, Iermakov, \& Harkusha, 2017; Ivashchenko, Khudolii, Iermakov, Chernenko, \& Honcharenko, 2018).

The study confirmed the effectiveness of using factorial designs to obtain objective data on the dynamics of training effects in primary school pupils (Ivashchenko et al., 2018; Khudolii et al., 2019). Factorial designs make it possible to neutralize the influence of unknown factors and increase the efficiency of research (Correa, Grima, \& Tort-Martorell, 2009, 2012).

Strength training of schoolchildren is seen as a necessary condition of the educational process (Ivashchenko, 2016, 2017; Kapkan, Khudolii, \& Bartik, 2019). Based on the analysis of structure coefficients (Table 5), it is possible to choose a load by focus, based on the analysis of centroids (Table 6), a total load can be chosen.

\section{Conclusions}

Thus, the strength training of boys aged 8 years can be planned depending on the objectives of schoolchildren's educational process:

- if the educational program requires a certain level of speed strength development, the fourth variant of strength load is used;

- if the initial level of strength development is insufficient to master the movement, then in the series of lessons the second and fourth variants of strength load are used;

- if the strength of a particular muscle group is a priority for developing a motor skill, then the variant of strength load is chosen accordingly.

\section{Conflict of Interest}

The author declares no conflict of interests.

\section{References}

Ivashchenko, O.V. (2016). Modelling of physical education students. Kharkiv: OVS. (in Ukrainian)

Bosenko, A. I. (2016). Vikovi i statevi osoblyvosti formuvannia ta reaktsii na fizychni navantazhennia systemy keruvannia rukhamy u shkoliariv 7-16 rokiv. Visnyk Chernihivskoho natsionalnoho pedahohichnoho universytetu. Seriia: Pedahohichni nauky. Fizychne vykhovannia ta sport, 139(1), 34-39. http://nbuv.gov.ua/UJRN/ VchdpuPN_2016_139\%281\%29_10 (in Ukrainian)

Veremeenko, V. (2019). Motor Abilities: Peculiarities of Strength and Strength Endurance Development in Middle-School-Aged Girls in a 4-Week Physical Training Cycle. Teoriâ ta Metodika Fizičnogo Vihovannâ, 19(2), 7688. https://doi.org/10.17309/tmfv.2019.2.04

Kuramshin, Iu.F., Grigorev, V.I., \& Latysheva, M.E. (2004). Teoriia i metodika fizicheskoi kultury. M.: Sovetskii sport, 436. (in Russian)

Veremeenko, V. (2019). Motor Abilities: Methods of Strength and Strength Endurance Development in Middle-SchoolAged Boys. Teoriâ ta Metodika Fizičnogo Vihovannâ, 19(1), 3-13. https://doi.org/10.17309/tmfv.2019.1.01

Khudolii, O. M., \& Ivashchenko, O. V. (2014). Modeliuvannia protsesu navchannia ta rozvytku rukhovykh zdibnostei $u$ ditei i pidlitkiv: Monohrafiia. Kharkiv: OVS, 320. (in Ukrainian)

Washabaugh, E. P., Augenstein, T. E., \& Krishnan, C. (2020). Functional resistance training during walking: Mode of application differentially affects gait biomechanics and muscle activation patterns. Gait \& Posture, 75, 129-136. https://doi.org/10.1016/j.gaitpost.2019.10.024 
Benzing, V., \& Schmidt, M. (2019). The effect of exergaming on executive functions in children with ADHD: A randomized clinical trial. Scandinavian Journal of Medicine \& Science in Sports, 29(8), 1243-1253. https://doi.org/10.1111/sms.13446

Bogdanis, G. C., Donti, O., Papia, A., Donti, A., Apostolidis, N., \& Sands, W. A. (2019). Effect of Plyometric Training on Jumping, Sprinting and Change of Direction Speed in Child Female Athletes. Sports, 7(5), 116. https://doi.org/10.3390/sports7050116

Lovric, F., Mandic Jelaska, P., \& Bilic, Z. (2018). Physical activity cannot be treated as a predictor of anthropological status among six-year-old children. Montenegrin Journal of Sports Science and Medicine, 7(1), 53-57. https://doi.org/10.26773/mjssm.180307

Marttinen, R., N. Fredrick, R., III, \& Silverman, S. S. (2018). Middle school students' free-living physical activity on physical education days, non-physical education days, and weekends. Montenegrin Journal of Sports Science and Medicine, 7(1), 5-12.

https://doi.org/10.26773/mjssm.180301

Ivashchenko, O. (2017). Classification of 11-13 yrs girls' motor fitness, considering level of physical exercises' mastering. Pedagogics, Psychology, Medical-Biological Problems of Physical Training and Sports, 21(2), 65-70. https://doi.org/10.15561/18189172.2017.0203

Cieślicka, M., \& Ivashchenko, O. (2017). Features of formation of the cumulative effect of power loads in boys 7 years old. Journal of Education, Health and Sport, 7(1), 198-208. https://doi.org/10.5281/zenodo.250599

Correa, A. A., Grima, P., \& Tort-Martorell, X. (2009). Experimentation order with good properties for $2^{\mathrm{k}}$ factorial designs. Journal of Applied Statistics, 36(7), 743754. https://doi.org/10.1080/02664760802499337

Correa, A. A., Grima, P., \& Tort-Martorell, X. (2012). Experimentation order in factorial designs: new findings. Journal of Applied Statistics, 39(7), 1577-1591. https://doi.org/10.1080/02664763.2012.661706

Ivashchenko, O., Khudolii, O., Iermakov, S., \& Harkusha, S. (2017). Physical exercises' mastering level in classification of motor preparedness of 11-13 years old boys. Journal of
Physical Education and Sport, 17(3), 1031-1036. https://doi.org/10.7752/jpes.2017.03158

Ivashchenko, O., Khudolii, O., Iermakov, S., Chernenko, S. \& Honcharenko, O. (2018). Full factorial experiment and discriminant analysis in determining peculiarities of motor skills development in boys aged 9. Journal of Physical Education and Sport, 18(4s), 1958-1965. https://doi.org/10.7752/jpes.2018.s4289

Ivashchenko, O., Nosko, Y., \& Ferents, V. (2019). Strength Abilities: Dynamics of Training Effect of Strength Exercises in Girls Aged 9. Teoriâ ta Metodika Fizičnogo Vihovannâ, 19(4), 200-208. https://doi.org/10.17309/tmfv.2019.4.06 (in Ukrainian)

Kapkan, O., Khudolii, O., \& Bartik, P. (2019). Pattern Recognition: Motor Skills Development in Girls Aged 15 Teoriâ ta Metodika Fizičnogo Vihovannâ, 19(1), 44-52. https://doi.org/10.17309/tmfv.2019.1.06

Khudolii, O., Ivashchenko, O., Iermakov, S., Veremeenko, V. \& Lopatiev, A. (2019). Motor Abilities: Identification of Development Level in Boys Aged 12-14. Teoriâ ta Metodika Fizičnogo Vihovannâ, 19(3), 139-147. https://doi.org/10.17309/tmfv.2019.3.05

Khudolii, O.M., Ivashchenko, O.V., Iermakov, S.S., Nosko, Yu.M., \& Marchenko, S.I. (2019). Strength Abilities: Estimation of Immediate Training Effect of Strength Loads in Girls Aged 7 Years. Teoriâ ta Metodika Fizičnogo Vihovannâ, 19(2), 98-104. https://doi.org/10.17309/tmfv.2019.2.06

Wertheimer, V., Antekolovic, L., \& Matkovic, B. R. (2018). Muscle damage indicators after land and aquatic plyometric training programmes. Montenegrin Journal of Sports Science and Medicine, 7(1), 13-19. https://doi.org/10.26773/mjssm.180302

Khudolii, O., Iermakov, S., \& Bartik, P. (2020). Didactics: Methodological Basis of Motor Learning in Children and Adolescents. Journal of Learning Theory and Methodology, 1(1), 5-13. https://doi.org/10.17309/jltm.2020.1.01

\title{
СИЛОВІ ЗДІБНОСТІ: ОЦІНКА ТРЕНУВАЛЬНИХ ЕФЕКТІВ СИЛОВИХ НАВАНТАЖЕНЬ У ХЛОПЦІВ 8 РОКІВ
}

\author{
Сергій Єрмаков $^{1 A B C D}$, Ольга Іващенко ${ }^{2 A B C D}$, Олег Худолій ${ }^{2 A B C D}$, Сергій Черненко ${ }^{3 A B C D}$ \\ ${ }^{1}$ Гданський університет фізичного виховання і спорту \\ ${ }^{2}$ Харківський національний педагогічний університет імені Г. С. Сковороди \\ ${ }^{3}$ Донбаська державна машинобудівна академія
}

Авторський вклад: А - дизайн дослідження; В - збір даних; C - статаналіз; D - підготовка рукопису; Е - збір коштів

Реферат. Стаття: 8 с., 6 табл., 22 джерела

Метою даної роботи є визначення впливу режимів виконання силових вправ на динаміку тренувальних ефектів у хлопців 8 років.

Матеріали і методи. У дослідженні прийняли участь 48 хлопців 8 років. Експеримент був проведений за планом факторного експерименту $2^{2}$. Був реалізований перший варіант комбінованого методу для розвитку м'язів рук і плечового поясу (станція I), сили м'язів черевного преса (станція II), сили м'язів спини (станція III) і сили м'язів ніг (станція IV). Матеріали дослідження опрацьовані в програмі статистичного аналізу - IBM SPSS 22. Здійснений дискримінантний аналіз. Вивчався вплив чотирьох варіантів силового навантаження на терміновий тренувальний ефект $\left(\mathrm{TTE}_{1}\right)$ після виконання вправ 
на чотирьох станціях, терміновий тренувальний ефект $\left(\mathrm{TTE}_{2}\right)$ після заняття та відставлений тренувальний ефект (ВТЕ) - через 24 години після заняття.

Результати. Кожний з варіантів силового навантаження може бути ефективно використаний у залежності від навчальних завдань як одного так і серії уроків фізичної культури, а також вказують на те, що ТTE і BTE силових вправ залежить від початкового рівня підготовленості та сумарного обсягу силових вправ в уроці фізичної культури. Силова підготовка школярів розглядається як необхідна умова навчального процесу. На основі аналізу структурних коефіцієнтів можливий ви- бір навантаження за спрямованістю, на основі аналізу центроїдів - вибір сумарного навантаження.

Висновки. Отримані дані вказують на можливість використання дискримінантної функції для оцінки і прогнозування розвитку сили у хлопців восьми років. У процесі дослідження підтверджена ефективність використання планів факторного експерименту для отримання об'єктивних даних про динаміку тренувальних ефектів у школярів молодших класів.

Ключові слова: хлопці 8 років, тренувальні ефекти, силові вправи, комбінований метод розвитку сили, дискримінантний аналіз, план факторного експерименту.

\section{Information about the authors:}

Iermakov S. S.: sportart@gmail.com; https://orcid.org/0000-0002-5039-4517; Department of Sports, Gdansk University of Physical Education and Sport, Kasimir Gorskogo St, 1, 80-336 Gdansk, Poland.

Ivashchenko O.V.: o.ivashchenko@yahoo.com; https://orcid.org/0000-0002-2708-5636; Department of Theory and Methodology of Physical Education, H. S. Skovoroda Kharkiv National Pedagogical University, Alchevskykh St, 29, Kharkiv, 61002, Ukraine.

Khudolii O.M.: khudolii.oleg@gmail.com; https://orcid.org/0000-0002-5605-9939; Department of Theory and Methodology of Physical Education, H. S. Skovoroda Kharkiv National Pedagogical University, Alchevskykh St, 29, Kharkiv, 61002, Ukraine.

Chernenko S.O.: chernenko.sergey65@ukr.net; https://orcid.org/0000-0001-9375-4220; Department of Physical Education, Donbas State Engineering Academy, Akademichna St, 72, Kramatorsk, 84313, Ukraine.

Cite this article as: Iermakov, S., Ivashchenko, O., Khudolii, O., \& Chernenko, S. (2020). Strength Abilities: Assessment of Training Effects of Strength Loads in Boys Aged 8 Years. Teoriâ ta Metodika Fizičnogo Vihovannâ, 20(3), 174-181. https://doi.org/10.17309/tmfv.2020.3.07

Received: 10.07.2020. Accepted: 20.09.2020. Published: 25.09.2020

This work is licensed under a Creative Commons Attribution 4.0 International License (http://creativecommons.org/licenses/by/4.0). 